\title{
A RESEARCH ON HUMANISM IN THE ZOROASTRIAN GATHAS
}

\author{
Sayed Asghar Hashimi \\ Education Faculty's Lecturer \\ Pashto Language and Literature Department \\ Sayed Jamaldin University, Afghanistan \\ E-mail: hashimi.saidasghar1@gmail.com \\ Sayed Ghani Ghani \\ Education Faculty's Lecturer \\ Pashto Language and Literature Department \\ Nangarhar University, Afghanistan \\ E-mail: ghanisayedghani@gmail.com \\ Shafiqullah Rahmani \\ Education Faculty's Lecturer \\ Pashto Language and Literature Department \\ Nangarhar University, Afghanistan \\ E-mail: ShafiqullahRahmani88@gmail.com
}

\begin{abstract}
In this article, human thoughts and the idea of human sympathy with human in Zoroaster's Gathas have been presented which forms a fundamental part of the theory of humanism. Quotes of Zoroaster have been taken from the Gathas and after analysis; their humanistic thinking has been clarified. The research has introduction to Gathas, what humanism is, and also contains information about Zoroaster. The material has been taken from books and has been clearly explained and elaborated. The purpose of the article is to shed light on human originality in Zoroastrian quotes. This is a library research and its method is explanatory and descriptive. The findings of this article is that in the Gathas (collection of quotes) of Zoroaster, human thoughts and guidelines, like other religions, are evident and he has been manifested as a good human being. The value of this writing lies in the fact that human guidance has been offered to human beings and Zoroaster provides ideas as a humanist and his human advice form the basis and foundation for the human beings of the society.
\end{abstract}

Keywords: Zoroaster, Gathas, Humanism, Human, Humanistic Originality.

\section{INTRODUCTION}

Zoroaster, a great thinker in the Avesta language, talks about human guidance in his speeches (Gathas) and his views are similar to those of other heavenly and earthly religions and great scholars. The commonalities of humanism in many religions indicate that the struggle for human welfare has a long background and Zoroaster preached to his followers to do well and not to do 
evil, and his quotes have mentioned in various places in his Gathas. Everywhere in the article where examples of Gathas have been given, the translation reveals that Zoroaster was a great, sympathetic and humanist man. He tells his followers to think well of other people and themselves, to speak well at all times and to do good deeds. This article cites examples from Zoroaster and reveals his universal human thinking.

\section{RESEARCH OBJECTIVE}

This research revealed humanistic views in Zoroastrian thoughts and this achievement can help the people of the society to do well and not to do badly.

\section{RESEARCH QUESTION}

Are there ideas about humanitarianism in Zoroastrian Gathas? Are there commonalities of humanism between Zoroastrianism and other heavenly and earthly religions or not?

\section{REVIEW OF THE LITERATURE}

Not much research has been done on Zoroastrianism in Pashto literature, nor has it been expressed in humanistic terms. Yet I mention the works which gives an idea of Zoroaster's. Gathas and speaks of his human thoughts.

Azmun (2020) talks about humanitarianism of Zoroaster. He mentions his good thoughts, good speech and good deeds in his quotes and these three points a direct relationship with humanistic thoughts. Zoroaster as a good humanist, preachers to his followers and encourages them to the right path.

(The Study of Humanism in Second Period Poetry) is his doctoral thesis. Part of the thesis is devoted to theory, part of which deals with humanitarianism in religions. A large part of the book on humanism in Zoroastrian thoughts. In his Gathas, there is a mutual relationship between human and God, human and human and human and other things.

Wazeer (2012) wrote M. Phil thesis. His thesis discusses Zoroastrian philanthropic ideas and makes it clear that Zoroastrian ideas are related to the heavenly and earthly religions and that Zoroaster being a leading leader is a great thinker and role model for his followers as. His human thoughts are related to universal human thoughts.

Azmun (2020) in his book (Philosophy of Literature) talks about Zoroaster and considers him as a great scholar and thinker who gives human guidance to his followers as a leader. He values human so much that his religion has no much difference with heavenly religions. There are no words in Zoroastrian views which are contradictory to human or humanity.

\section{METHOD OF THE RESEARCH}

Library research has been used in writing this article, which includes the author's main reference books, as well as various works that deal with the subject matter. The method of this research is descriptive and explanatory and in some places analysis and interpretation have been used. In this method, quotations have been made from various works related to the subject and a conclusion has been taken after explanation and clarification.

\section{FINDINGS}

To conclude, it can be said that Zoroaster led a large tribe and people and, like the leaders of other heavenly and earthly religions, had a high human thought. His words are good examples for 
those who advise their followers (human beings) to refrain from any kind of evil deeds and remind them of good thoughts, words and deeds.

All of his instructions are humane, and his Gathas are worth mentioning, which have been brought as examples in this article, and they can prove his humanistic worldview.

Each of his instructions is for the goodness of human. He emphasizes the good and instructs not to do the bad. He comes as a great preacher and leader and guides and advises others to be good human beings by having the characteristics of a good human being. The purpose of this article is to show that the time of human birth and the ascension of humanity are related to human development and human good deeds. The decline of human begins when human rights are violated and ignored in a society and Zoroaster's Gathas are a good example of human guidance that illuminates his humanistic thinking.

\section{DISCUSSION}

Among the world religions, Zoroastrianism is the religion that has given very good humanistic guidance to its followers. They consider the three most important sayings of their religion in Persian-Dari literature (Kardar-e-Nek, Guftar-e-Nek and Andisha-e-Nek) meaning good deeds, good speech and good thinking.

Based on humanism, if these three words are analyzed and interpreted, books can be written on them and all aspects of humanism can be found in them. They are in favor of improvement in all things, emphasize good words in daily life and seek good thoughts for good speech and good deeds.

Humanism is the part of human origin that is used to achieve human rights and the movement has an ancient background of defending human rights and made great progress during the Renaissance.

Zoroastrian human thought is mentioned in Gathas and the purpose of this work is to study and research humanistic ideas in the Gathas.

It says bout the name of Zoroaster: "Zoroaster name in Avesta is (Zara Thoshtra), "Zart" means yellow, golden or one who has lord and (Ashtra) means (SHUTAR) in Persian-Dari and $(\mathrm{OUKH})$ in Pashto language and sometimes it means star. Zoroaster received spiritual education and training in his childhood and in Gathas, he calls himself (Zotar) which means a person who is a follower of religion, a perfect spiritual figure" (Wikipedia, n.d.). "Researchers do not have the same consensus about his living place and place of birth, the famous historian Tabari thinks Zoroaster and his followers were from Palestine and adds that they came to Ariana from there, but the correct and strong consensus is that he was from Azerbaijan. There are different consensuses about the time and his place of living, some of which show his life as early as $6000 \mathrm{BC}$, but the popular consensus is that he was born 660 years Before Christian Era. He died 583 years before Christian Era at the age of 77 in Balkh, Afghanistan." (Tawfiqi, 2006) Many scholars and researchers do not agree on Zoroaster, some deny his existence and some accept it. Zarathushtra's Gathas which is a part of his book talks about (Zardasht, Zartasht, Zaradasht, Zaratasht, Zardhasht and so on), where (Zard Ashter) means a yellow camel. His father's name was Pourušaspa meaning "old horse", his mother's name was "Dughdow" meaning a cow that gives milk. His family name was Spitama, which means white race.

Humanism historically evolved from the Latin word (homo) in the eighteenth century as a common gender name of human. It originally termed terrestrial beings (humans and animals) and the word is considered to have come from the Old Latin language root (HOMO) (Mangal, 2011). The word "humanism" has derived from the Latin word "humanus". In the general sense, it means 
humanism, humanitarianism and altruism, but the most beautiful meaning of humanism, in respect to human virtue, is a set of ideas that determine the destiny of human beings and human happiness, virtue and freedom. Therefore, it can be said that humanism is a progressive tendency in the thinking of humanity, which manifests a great love for human, opposes cruelty, oppression, prejudice, hatred and narrow-mindedness, and is manifested by having the human-friendly nature in the higher stages of evolution (Mandozai, 1988). As Zoroaster, Humanism, and Gathas have been mentioned in the title, therefore I spoke briefly about Zoroaster and Humanism. Gathas is Zoroaster's quotes that represents his thoughts and scholarship and clarifies his human thoughts. Also, In terms of the content, his speeches other than other topics include humanism, humanitarianism and altruism.

In Zoroastrianism, the followers are recommended to think, talk and to do good deeds. Based on these three characteristics, humans come closer to (Sifat, n.d.). In their religion, Ahura seeks good and Ahirman seeks evil. The war of good and evil is going on and each side wants to defeat the other. In their religion there are these contradictory sides and one seems to be antagonistic to the other but in fact, every antagonistic phenomenon is not to the detriment of the other, but to the benefit of one another.

The fact is that there is a law of contradictions in the universe, so life is moving in the right direction toward development, and new situations arise from the collision of contradictions, and things are slowly approaching their true existential individuality and perfection (Shinwari, 2004). From the above, it is clear that Zoroaster had a great hand in the implementation of human thought and had many human associations with other religions, scholars and thinkers. Many of the teachings in Zoroastrianism and its constitution are related to Islam, the Torah, the Psalms, the Gospel, Buddhism, Hinduism, and so on, largely because of the common human characteristics.

\section{Zoroaster and Human Guidelines}

In Zoroaster's quotes, there are many social issues in terms of contents which are so important for humans and human guidance. His religion is a human religion and values human highly. Many of his guidelines represent him and he is a great role model to his followers. He says:

(Brothers, I swear to you to be loyal to your homeland (Abdullahi, 2012). Zoroastrianism, like other religions and practices, emphasizes human teachings, and the basis of this approach to human, laid down by Zoroaster, is very practical. Many of his thoughts, ideas and sayings are about human and human teachings, and have a lot in common with other religions. Zoroastrianism originated approximately a century before the Christian era and was known as Mazdistan. In their religion, the subject of Ahura Mazda is related to this Mazdist and the subject of Ahura Mazda is directly related to humanism.

(According to Zoroaster, there is no good or evil in the laws of nature, but cruelty and brutality, good and evil, goodness and evilness, are related to human thought, and man chooses them. He calls on truth seekers and scholars to pay attention to this fact. Good and evil coincide in human thought and are reflected in human action, speech and thought.

The above discussion shows that thought and rationality are important topics for human beings. A lot of things and actions have to do a lot with thought. Guidance to external senses also comes from thought. From the point of view of their religion, there is no such thing as good or evil in the world because there are no distinct gods for good and evil. It is a human being who does good and evil in his thoughts and actions. Man is free in his actions. Here man is given the right to do good deeds, but it is important to note that there are some forced deeds that are imposed on human. Zoroastrianism in terms of monotheism, the creation of the universe, the belief in angels, 
the afterlife, the Day of Judgment, heaven, hell, and the ethical teachings seems very similar with basic principles and ethics of Islam. Zoroastrianism emphasizes the purity of thought or intentions, because actions are based on thoughts or intentions (Wazir, 2012). In the Zoroastrian religion, belief in another life after death paves the way for discussions of humanism and humanitarianism. Rewarding good people with heaven and punishing bad people with hell for doing evil deeds, ethical preaching, holy thoughts, and other such instructions are for human beings to do well and not to do evil.

Zoroaster emphasizes (Kardar-e-Nek, Pandar-e-Nek, and Guftar-e-Nek) meaning good deeds, good speech and good thinking and almost all religions have the same opinion in this regard.

(Pandar) means thought, guessing, and imagination (Farhang, 2002). Zoroaster says about human (materialistic and spiritual) improvement: "Zoroaster mentions the dual structure of human. In the Avesta, these two aspects are called Urvan (the soul) and Tanu (the body). These two dimensions are divided into material and spiritual. This is an aspect that is immortal and there are a lot of points about it in the Avesta. The Urvan in the Avesta language, without referring to the immaterial side of human, is one of the five forces of man (Shieda, 2014). This discussion requires research based on the human body and soul. (Tanu) is the body of human and (Urvan) is the spiritual side, essence and psychological side of human.

In Zoroaster's opinion, a good person is one who is cooperative and friendly to other human beings, is kind-hearted, generous and truthful, fights against human oppression, and seeks peace in society. Human can acquire Ahurai attributes based on his/her inner characteristics; these attributes represent goodness and can reach the level of self-knowledge. In this position of knowledge the human soul is connected to the Ahura Mazda and becomes eternal. To identify Ahura Mazda, it leads to the creation of a relationship between the universe and human beings.

Some of the Avesta examples show that Ahriman is an old concept like Ahuramazda and is by no means a descendant of Ahuramazda. Ahuramazda discovered but did not create, but in some of the Avesta prestigious books, it is said that Ahuramazda created two things: (Spant Mainu) which means sacred knowledge and good and (Ingra Mainu) which means badness and evil. Ingram Mainu means Ahuramazda and Spant Mainu. You can be called Ahriman. Some believe that Ahriman was created by Ahuramazda, but others believe that if Ahura is the creator of Ahrimani forces, then the meaning of Ahura is proved wrong. Ahrimani forces have their own independent and unique identity. According to Zoroaster, the creator of all things, Ahuramazda, is invalid, and there is another creator who has created the whole universe.

In Zoroastrian culture, without self-knowledge, human must know nature and beings and their surroundings as much as he/she can and seek to appreciate Ahura. They consider human to be an extraordinary being and creature.) His thought, morals, and rationality are qualities that are not found in other beings (Nia, n.d.). Zoroaster speaks of self-knowledge. Good communication with other people, good behavior with people and other universes in daily life, the main place of action and character which is thought, having (good thinking), is important in human self-knowledge. They tell humans not to know nature and beings without knowing themselves. Knowing the universe knows the Creator. Their (Ahurayee) is good deeds and goodness.

They value human very much. Giving human beings a good position differs in their religion from renaissance and modern humanism. They consider human a created being that has a creator behind them, but atheist humanism has different opinions about human creation.

He mentions the individual characteristics of human, appreciates his rationality. The fact is that no creature in the world can perform the same mental and intellectual functions as a human being. Their well-being and moral actions are not the work of other beings. Zoroastrianism is not 
limited to philosophical and spiritual teachings. He seeks luckiness and prosperity for all human beings and hates isolation. (According to Zoroastrianism, Adam is the representative of God on earth. An important feature of Zoroastrianism is the freedom and choice of the human being. Human has the right to choose his/her own path and is free and can choose the right path based on choice (Nia, n.d.).

In the religion of Zoroastrianism, free will is given a high preference; even many people call it (free will religion). Zoroastrian Gathas and philanthropy.

\section{Zoroastrian Gathas and Philanthropy}

Zoroastrianism has a lot to say about human authenticity. He instructs, forbids evil, preaches well, and speaks much of his religion for the good of mankind. Throughout history, nearly four thousand years ago, an eager seeker of truth and light emerged who guided man to the worship of the One God. What he had found about self-knowledge and God-knowledge, through self-research and world-research, he conveyed it to the people in the Manuvi hymns, for training them. He said that Allah is one and that human has the duty to preserve and cultivate the earth on the path of truth. His life was a guide to good deeds, his message was a guide to optimism, and his thoughts were a guide to good deeds)

The Gathas:

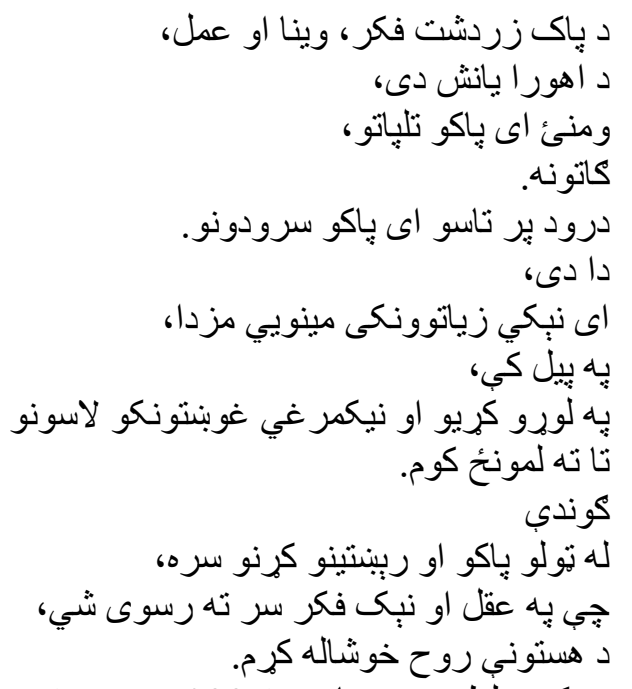

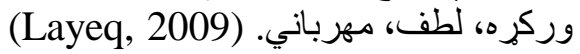

The meaning of this Zoroastrian quote is: Pure thought, speech and action in the above examples indicate that there is good and bad in everything, pure and impure. He talks about good thought, speech and action.

The worship of one God and the supplication to Him prove the relationship between human and God and these relationships were for a specific purpose. In the previous discussion, I mentioned that the rights of worshipers are the rights of God and if a person does the rights of God, he does not do wrong to human. They present good and pure deeds in these three words. Good deeds must be proven in speech, shown in action and is the result of good thinking that makes a person good. He asks for kindness, Sympathy and generosity to human beings.

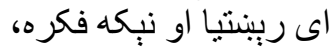

$$
\begin{aligned}
& \text { او اي مزدا اهورا، } \\
& \text { زه تاسو ته سرود و ايم، الهورا، }
\end{aligned}
$$

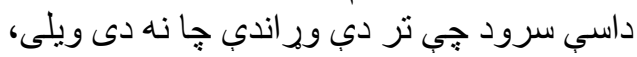




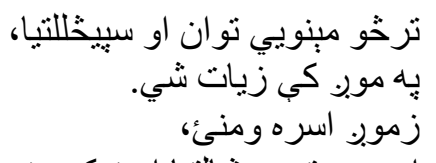

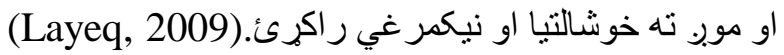

In the Gathas, it is said: Zoroaster seeks spiritual purity, it is found in pure inner and internal construction. Internal cleansing is essential for this cleansing. They want human beings to have the spiritual power of physical ability over themselves, in this power human does good to human, the meaning of human's name can be found in human. He sees happiness in spiritual power shows the place of happiness in the inner world and shows the place of happiness in the world of (Andurn).

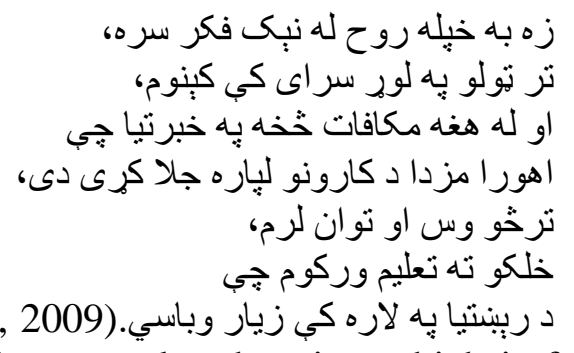

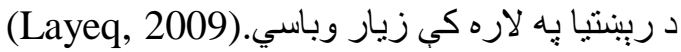

The translation of Zoroastrian's quote is: Zoroaster gives people education which is for a successful life. He shows the domination of the soul over thought. Strengthening the soul is possible through good thinking. He also preaches the truth. The status of man's greatness is not based on his material side, but on the attitude of the divine spirit in which the extraordinary talents lie and can be the light of God's manifestation. The only way to evolve is to strengthen one's soul, and materialistic things have been created for the soul to reach its goal, and materials are its tools.

The outer structure of human is made of soil; the soul is cast into it. All human organs are the means by which the soul reaches its goal.

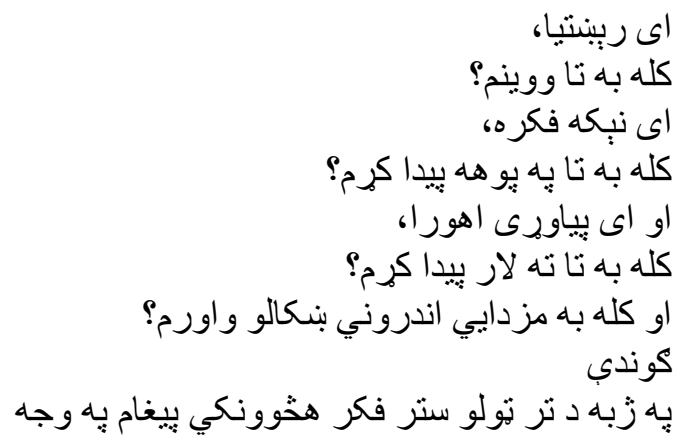

لار وركو ته لار بنيم. (Layeq, 2009)

Zoroaster says: Zoroaster advises to tell the truth. He wants it in people and society. He seeks good thinking in knowledge, that is, through knowledge good thinking is created, produced, and through it humans can serve themselves and all human beings.

All of the above examples of Gathas are preaching Zoroastrianism in the form of human advice. He speaks for the guidance of the people, calls them to good and forbids them from evil. He worships, believes in death and life and talks about goodness (Haq, 2012). When Zoroaster reached a town near the forest! There, he saw a large crowd gathered in a large field. Because people had heard that a rope-player would be walking on a rope in the air. Zoroaster turned to the people and said, "I teach you the lesson of the higher human. Human is something that requires going up. What have you done to ascend? All beings have created a thing so far which is higher than them and you want to be a part of this big wave and instead of rising above human, you 
descend towards the beast. What does a human being think of a monkey? A thing of laughing and a thing of painful shame and a great human will look at the human as a mockery and a painful shame (Azmun, 2020). Zoroastrianism and other religions have talked a lot about human values. Some ideologies have many common points. Each religion has its own approach and its own ideas. The heavenly religions have all been abolished, only Islam is the complete religion for humanity and Islam (Boise, 2019). As for other religions, I would say that most of their teachings are for the benefit of human beings and some of them contradict Islam. Islam is the only religion and law that contains all the ancient human ideas, except the erroneous ones.

\section{SUGGESTION AND CONCLUSION}

If we further research the Zoroastrian Gathas and study their contents, we will learn many new things. Zoroaster should be read and his guidelines should implement in practical life. Also, the guidelines that he presents to human beings should be practiced because they are important. According to his guidelines people should avoid doing thing which are bad. Zoroaster as a great human and scholar preaches to his people and gives them a thought of humanitarianism. Therefore, every human being is supposed to implement his thoughts and refrain from doing bad things. I ask other researchers to research on other sides of Zoroaster as well.

The conclusion of this research is there are appreciable human related views in Zoroastrian Gathas which has a lot about humanitarianism. He as a great leader guides people, leads them to the right path and forbids them from doing bad things. His thoughts have relationship with many religions as well as directly or indirectly with the views of the world's great scholars and philosophers.

\section{ACKNOWLEDGMENTS}

Authors would like to thank the anonymous participants for their cooperation and time in providing the researcher all the needed information.

\section{REFERENCES}

Azmun, L. P. (2020). Philosophy of Literature. Kabul: Academy of Sciences of Afghanistan, Department of Information and Public Relations. P444.

Abdullahi, M. (2012). The foundations of the philosophical humanities. Iran: Research in Islamic Culture and Thought. P63.

Boise, M. (2019). Zoroastrian beliefs and religious etiquette. Second edition. Translated by Askar Bahrami: Tehran. Iran. p266.

Farhang, A. (2002). Iran: Tehran. First volume, p547.

Haq, M. S. (2012). The basics of the humanities from a religious point of view. Second year. Number seven. Scientific Journal - Research. P22.

Layeq, S. (2009). Gathas, Zoroastrian menu hymns. Kabul: Bahir Press. P1, 2, 3, 3.

Mandozai, M. W. (1988). Ethics and Humanism. Kabul: Academy of Sciences of Afghanistan. P62. 
Mangal, S. (2011). Humanism from the point of view of Eastern and Western philosophers. Peshawar. War Magazine. P19.

Nia, H. T. (n.d.). The purpose and goal of man in this religion. Irfan Magazine. P83, 3.

Shida, R. (2014). A look at the anthropology of Zoroastrianism and the inference of training. Fifth year. Number two. Piapi 2. P3.

Shinwari, H. (2004). The human ego and knowledge. (Second Edition). Peshawar: University Book Agency. P115.

Sefat, I. N. (n.d.). Methods, principles and theories of perfect human beings in Islam and humanism. Seventh year, No. 1. P100.

Tawfiqi, H. (2006). Get acquainted with Zoroastrianism. Treasure education. P2.

Wazir, M. (2012). Humanism in Pashto classical poetry. Peshawar, University Book Agency. P26.

Wikipedia. Google. Zoroaster. Encyclopedia. Free. (n.d.) P3.

\section{Copyrights}

Copyright for this article is retained by the author(s), with first publication rights granted to the journal. This is an open-access article distributed under the terms and conditions of the Creative Commons Attribution license (http://creativecommons.org/licenses/by/4.0) 